Monika Grochalska

Uniwersytet Warmińsko-Mazurski

\title{
Perspektywa krytyczna w badaniach nad intymnością
}

Intymność zdaje się być częściej obiektem zainteresowania różnej maści psychodoradców piszących teksty dla internetowych serwisów poradnikowych niż przedmiotem badań naukowych. Gdy trzeba intymność zdefiniować na potrzeby dociekań i analiz naukowych, okazuje się, że nie jest to łatwe. Narzucają się zewsząd obiegowe opinie i zbanalizowane do granic możliwości popularne definicje. Okazuje się, że bardziej „czujemy”, czym jest intymność, niż rzeczywiście wiemy, co owo słowo oznacza. Jest to sfera życia nader często tabuizowana, a jednocześnie bardzo idealizowana. Niniejszy tekst ma za zadanie przedstawić najbardziej adekwatne naukowe definicje tego, co w codziennym życiu zwykliśmy zwać intymnością, a jednocześnie nieco „odczarować” tę sferę ludzkiego doświadczania. Jednocześnie podjęta zostanie próba ukazania przydatności perspektywy krytycznej w procesie odkrywania licznych znaczeń intymności. Są one związane nierozerwalnie ze zmiennymi $\mathrm{w}$ czasie i ulegającymi nieprzerwanie rozlicznym modyfikacjom dyskursami miłości, które obecne stale w przestrzeni publicznej przenikają także do świata nauki, przyczyniając się jednocześnie do dominacji jednego, stosunkowo sztywnego schematu interpretacyjnego obowiązującego $\mathrm{w}$ badaniach nad tymi najbardziej osobistymi obszarami codziennego życia. Wreszcie przytoczone zostaną wybrane kategorie teorii Pierre'a Bourdieu i Michela Foucault wraz ze wskazaniem na możliwe sposoby ich wykorzystania jako nowych ram analitycznych, służących "odtabuizowaniu" i przydatnych w badaniu ukrytych aspektów związków intymnych.

W polskiej pedagogice społecznej i socjologii rodziny dominuje dyskurs intymności rodzinnej. Jest to sfera definiowana z punktu widzenia relacji rodzinnych i małżeńskich, często idealizowana, ale bez pogłębionej analizy relacji między dwojgiem partnerów tworzących trzon rodziny, jak też bez analizy sposobów doświadczania przez nich intymności w związku (por. Ostrouch-Kamińska 2011, s. 31-40). Jest to temat pomijany i przemilczany. $Z$ założenia to, co intymne, pozostaje w sferze prywatności, dlatego intymność jawi się jako trudno definiowalny i nieuchwytny przedmiot badań.

W niniejszym artykule zostanie przedstawiony zarys możliwości krytycznej analizy związków intymnych przez pryzmat teorii społecznej Bourdieu oraz 
Foucaulta. Celem jest znalezienie odpowiedzi na pytanie, czy i w jakiej mierze perspektywa krytyczna pozwoli zinterpretować procesy konstruowania związków intymnych i wyobrażeń o nich oraz sposoby doświadczania relacji intymnych.

\section{Intymność - (re)definicje}

Według Roberta Sternberga (2007, s. 275-276; Wojciszke 2011, s. 336-338) intymność jest jednym ze składników miłości. Składa się na nią ogół pozytywnych uczuć wobec partnera i towarzyszących im działań. Można ją opisywać w kategoriach:

- pełnych ciepła i serdeczności kontaktów,

- zrozumienia,

- pocieszenia,

- życzliwości,

- oczucia bezpieczeństwa i spokoju w obecności partnera,

- polegania na partnerze,

- wsparcia i pomocy.

Tak pojmowana intymność bywa utożsamiana (Wojciszke 2010, s. 10-11):

- z pragnieniem dbania o dobro partnera,

- $\quad$ z przeżywaniem szczęścia w obecności partnera i z jego powodu,

- z szacunkiem do partnera,

- z przekonaniem, że można na niego liczyć w potrzebie,

- z wzajemnym zrozumieniem,

- $\quad$ z wzajemnym dzieleniem się przeżyciami i dobrami (duchowymi i materialnymi),

- $z$ dawaniem i otrzymywaniem uczuciowego wsparcia,

- z wymianą intymnych informacji,

- $\quad$ z uważaniem partnera za ważny element własnego życia.

Elementy te można traktować jako swego rodzaju zespół praktyk charakterystycznych dla związków intymnych. W myśl teorii Bourdieu są one generowane przez habitus.

Struktura intymności, czyli konfiguracja wyżej wymienionych czynników, nie zależy od tego, czy chodzi o miłość do partnera życiowego, ojca, matki, rodzeństwa czy też przyjaciela tej samej płci. Intymność pojawia się we wszystkich tych związkach z różną siłą, ale zawsze jest zbiorem przeżyć charakterystycznych dla miłości w ogóle (Wojciszke 2010).

Istotne jest także to, że intymność $\mathrm{w}$ związku stopniowo zanika - w fazie związku przyjacielskiego powstrzymanie spadku intymności staje się podstawowym problemem. Chodzi o utrzymanie wzajemnego przywiązania, lubienia się, zaufania, chęci pomagania i otrzymywania pomocy. Intymność zamiera pod wpływem egoizmu, nietolerancji, agresji, braku wsparcia czy zdrady (Wojciszke 2011, s. 345-346). Wydaje się jednak, że w niektórych związkach tak rozumiana in- 
tymność nie ma szansy się wykształcić w ogóle, bo takie czynniki, jak nietolerancja, agresja czy zdrada, występują od początku ich trwania. Mimo to za sprawą różnych mechanizmów, takich jak dyskurs „szczęśliwej rodziny” czy też mity małżeńskie i rodzinne (Kocik 2006, s. 80-90) przekazywane w toku socjalizacji, partnerzy nadal w nich trwają. Jednak jakiś rodzaj intymności w tych związkach także występuje. Sugeruje to, że psychologiczne ujęcie miłości jest niepełne.

W rzeczywistości intymność jest przedmiotem badań ledwie uchwytnym, rozproszonym, niedookreślonym. Pewne jest natomiast, że intymność wyraża się w praktykach podejmowanych wobec siebie przez partnerów, a równocześnie konstytuuje owe praktyki.

\section{Współczesne dyskursy miłości - idealizacja życia w parach}

Rzetelne badania nad poczuciem intymności utrudnia znacznie tendencja idealizowania związków rodzinno-małżeńskich, obecna także w nauce. Dokonuje się tego, opierając się w badaniach na "oczywistych” przesłankach wynikających z wszechobecnych dyskursów miłości. Zdaniem Macieja Gduli (2009) współcześnie (na podstawie analizy poradników miłosnych) można wyróżnić trzy główne dyskursy miłości obecne w sferze publicznej:

1) utopijny

Brakuje tu zewnętrznych kryteriów oceny związku, dominuje racjonalizacja dywagacje o sprawiedliwym podziale pracy i równowadze, a także założenie, że można pozostawać w bliskim związku, mimo że całkowicie komplementarna relacja nie jest możliwa z powodu niezaprzeczalnych „naturalnych” różnic między kobietami a mężczyznami. W tym dyskursie widoczne są nawiązania do socjobiologii.

2) utylitarny

Miłość jest tu przedstawiana jako gra. Związek jest definiowany w kategoriach zysków i strat - partnerzy dobierają się w pary tylko dlatego, że są w stanie razem wytworzyć więcej dóbr niż w pojedynkę. Związek powinien być zarządzany jak przedsiębiorstwo i traktowany jak długoterminowa inwestycja. Jest to dyskurs "zasilany" teorią wymiany społecznej.

3) tradycyjny

Podkreślana jest „naturalna” pełnia relacji damsko-męskiej, której „naturalnym” owocem są dzieci. Małżonkowie powinni panować nad swoją seksualnością - życie seksualne służy prokreacji. "Zgrzyty” w związku są efektem zepsucia kultury, zatem winą za rozpad związków jest obarczane niejako „toksyczne” otoczenie, a nie same zaangażowane w nie osoby. Ów dyskurs bliski jest dyskursowi konserwatywno-katolickiemu, a obecny często w badaniach nad strukturą i funkcjami rodziny w pedagogice.

Gdyby podjąć próbę zrekonstruowania definicji intymności obecnych w wymienionych dyskursach, to różnice będą znaczące. W dyskursie utopijnym zakłada się istnienie różnic, które sprawiają, że do niektórych zachowań wobec 
partnera predestynowane są kobiety, a do innych mężczyźni. Kobiety są bardziej skłonne dbać o partnera, przychodzi im to naturalnie. Ponadto co innego przynosi szczęście kobietom, a co innego mężczyznom - trzeba znać te wzajemne preferencje, aby móc zapewnić szczęście partnerowi. Szacunek do partnera opiera się na zrozumieniu ww. mechanizmów. Zakłada się, że w związku chodzi o dzielenie się dobrami i przeżyciami, ale czasami brakuje w nim miejsca na autentyczne zainteresowanie, i wówczas (dla dobra związku) trzeba udawać, że przeżycia partnera nas interesują. Dotyczy to zwłaszcza mężczyzn - nie mają oni naturalnego daru interesowania się przeżyciami partnerki. Dobrami materialnymi można „,kupić" szczęście drugiej osoby. Do udzielania uczuciowego wsparcia także bardziej skłonne są kobiety, natomiast mężczyźni muszą przyswoić w tym zakresie odpowiednie schematy działania. Dzielenie się informacjami intymnymi zazwyczaj służy osiągnięciu równoczesnej satysfakcji partnerów. Partner i sam związek jest elementem ważnym, ale jednocześnie utrudniającym życie.

W dyskursie utylitarnym składniki intymności są traktowane jako zasoby. Chodzi raczej o własne korzyści niż o dobro partnera. Szczęście osiąga się jedynie w sytuacji pomnożenia zysków. Szacunek do partnera pojawia się wtedy, gdy partner rzeczywiście pomaga te zyski pomnażać. Przekonanie, że można na siebie wzajemnie liczyć także jest związane z możliwością wzajemnego udzielania zasobów. Wspólny cel - pomnażanie zysków - sprawia, że partnerzy wzajemnie się rozumieją. Wartości materialne są nadrzędne w stosunku do duchowych $\mathrm{w}$ ich pozyskiwaniu przodują kobiety. W zakresie dawania i otrzymywania uczuciowego wsparcia też istnieje wyraźna asymetria - w tym zakresie to mężczyźni odnoszą większe korzyści. Wymiana informacji intymnych służy odniesieniu korzyści w postaci zaspokojenia. Związek i partner jest ważny tak długo, jak długo pomaga maksymalizować zyski.

W dyskursie tradycyjnym to mężczyzna ma zapewnić warunki materialne, a kobieta "infrastrukturę" domową. Dawanie i otrzymywanie uczuciowego wsparcia nie jest tak istotne - istotne są pozory. Wymiana informacji intymnych jest konieczna, aby np. zapobiec niechcianej ciąży - stosowanie naturalnych metod zapobiegania ciąży wymaga informowania partnera o dniach płodnych i bezpłodnych, w których można pozwolić sobie na zbliżenie seksualne. Partner i związek są w centrum hierarchii wartości, ale dlatego, że tak stanowią zewnętrzne normy.

Wszystkie te dyskursy łączy z nauką specyficzny dialektyczny związek. Ich elementy pochodzą z naukowych - psychologicznych, socjologicznych, pedagogicznych - rozważań, a jednocześnie ponownie wpływają na świadomośći sposób postrzegania sfery intymnej przez badaczy. Owe dyskursy rzadko przyczyniają się natomiast do poznania prawdziwego charakteru związków intymnych, ponieważ są zniewolone przez zewnętrzne normy, imperatywy moralne, uwarunkowania strukturalne i zinternalizowane przekonania na temat płciowości i seksualności. 


\section{O intymności krytycznie}

Warto zastanowić się, co może wnieść w obszar analizy relacji intymnych teoria krytyczna. Czym jest związek dwojga osób w świetle teorii krytycznej? Jakie niuanse pomijane $\mathrm{w}$ dominujących dyskursach pozwala uchwycić owa perspektywa?

W teorii Bourdieu kluczowymi elementami dla analizy związków intymnych są:

1) teoria praktyk, a zwłaszcza problematyka ich dostosowania do struktur (modeli konstruowanych na podstawie dyskursu),

2) problematyka nabywania praktyk jako mediacji między strukturą a układami, które są przez nią wytwarzane, i habitus - rozumiany jako efekt działania struktur i jednocześnie zasada uzewnętrzniania tego, co nabywane w postaci praktyk,

3) koncepcja przemocy symbolicznej - wyjaśniająca mechanizmy podporządkowania jednych grup społecznych innym i narzucania im perspektywy grup dominujących w oglądzie i ocenie rzeczywistości.

W kwestiach problematyki dostosowania praktyk życia intymnego do modeli uprzednio konstruowanych na podstawie dyskursu założenia Bourdieu (2008, s. 72) są następujące:

1) przedmioty poznania są skonstruowane a nie biernie rejestrowane, więc także intymność jest konstruowana,

2) zasadą tej konstrukcji jest system dyspozycji ustrukturowanych i strukturujących, tworzący się w praktyce i zawsze nastawiony na swe praktyczne funkcje.

Oznacza to, że na podstawie dominujących dyskursów w umysłach ludzi tworzą się reprezentacje związków, które warunkują kształt oczekiwań wobec tego typu relacji (spodziewane rezultaty) oraz podejmowane praktyki. Dyskursy jednak pomijają ważne aspekty związków intymnych, generując przez to powstawanie fałszywych reprezentacji takich relacji, a tym samym nierealistycznych oczekiwań wobec związku/partnera i praktyk niedostosowanych do stanu warunków obiektywnych. Funkcjonowanie w związku powoduje wówczas powstawanie dysonansów, które nieuchronnie prowadzą do modyfikacji reprezentacji. Ale ponieważ są one konstruktami reprezentowanymi, modyfikowanymi, podzielanymi i przekazywanymi $\mathrm{w}$ procesie interakcji, to proces ich modyfikacji zawsze jest w pewien sposób „skrzywiony” przez dyskurs, nigdy nie jest natomiast determinowany tylko przeszłymi doświadczeniami. Może zatem prowadzić do powstania kolejnych fałszywych reprezentacji związków, kolejnych niedostosowanych praktyk i kolejnych dysonansów.

Nawiązując natomiast do procesu nabywania praktyk, rozumianego jako mediacja między strukturą a układami, które są przez nią wytwarzane, nie sposób pominąć roli habitusu. Trzeba w tym miejscu przyjąć rozumienie habitusu jako efektu działania struktur i jednocześnie zasady uzewnętrzniania tego, co nabywane w postaci praktyk. Cytując Bourdieu: „Habitus stanowi zarówno zasadę 
generującą praktyki dające się obiektywnie klasyfikować, jak i system klasyfikowania tych praktyk. W relacji między tymi dwiema zdolnościami określającymi habitus ustanawia się społeczny świat przedstawiony, to znaczy przestrzeń stylów życia" (Bourdieu 2005, s. 216). Zatem można przyjąć, że to habitus generuje praktyki podejmowane wobec partnera $\mathrm{w}$ związku. Jeśli partnerzy są wyposażeni w odmienne habitusy, będą także generować inne praktyki, a także ich własne praktyki mogą być odczytywane przez partnera niezgodnie z intencjami. Zakładając przy tym, że kobiety i mężczyźni są wyposażeni w odmienne rodzajowe habitusy, z góry powinniśmy przyjąć pojawienie się szeregu kłopotów związanych z niedopasowaniem owych habitusów. Ponadto Bourdieu przyznaje, że: „System właściwości dobrze dobranych (w tym także osób), ma za podstawę gust, czyli system schematów klasyfikowania, które mogą docierać do świadomości jedynie cząstkowo, mimo iż w miarę jak wznosimy się w hierarchii społecznej, styl życia coraz większą wagę przyznaje temu, co Weber określa jako stylizację życia" (Bourdieu 2005, s. 220). Jedna z możliwych interpretacji tych słów zakłada, że kobiety i mężczyźni, mając odmienne habitusy, przyswajają sobie w toku socjalizacji odmienne schematy klasyfikowania praktyk, czyli wykształca się u nich inny gust. Dotyczy to w oczywisty sposób tego, co aprobują w sobie nawzajem partnerzy i czego od siebie oczekują. Proces socjalizacji sprawia, że nader często są to oczekiwania całkiem sprzeczne. Dziewczętom wpaja się życiowy skrypt polegający na poszukiwaniu czarującego, szarmanckiego i kochającego „księcia na białym rumaku". W życiu dorosłym okazuje się jednak, że jest deficyt książąt, a jest to związane z socjalizowaniem chłopców do dominacji nad kobietami, $w$ tym także $\mathrm{w}$ sferze erotycznej. Często jest to dominacja związana z przemocą fizyczną i nie ma wiele wspólnego z "miłością”, do której przygotowywane są dziewczęta. Używając skrótu myślowego: chłopcy oczekują, że ich życiowa partnerka będzie "wyuzdaną służącą", podczas gdy dziewczęta chcą być adorowanymi księżniczkami. W tej sytuacji oczywisty staje się konflikt interesów. To tłumaczy częste rozczarowania wobec pierwszych związków.

Rzadko doświadczenia intymne kończą się na tym pierwszym związku. Jak pisze Bourdieu: „Habitus, produkt historii, tworzy jednostkowe i zbiorowe praktyki, czyli historię, w myśl schematów wyłanianych przez historię: zapewnia aktywną obecność minionych doświadczeń złożonych w każdym organizmie postaci schematów postrzegania, myślenia i działania, dążąc do zagwarantowania zgodności praktyk i ich stałości w czasie pewniej, niż jakiekolwiek reguły formalne i wszelkie jawnie wyrażone normy" (Bourdieu 2008, s. 74). Wszystkie doświadczone i minione doświadczenia ",bycia-w-związku” - w sensie jednostkowym i zbiorowym sprawiają, że nabywamy schematy postrzegania, myślenia i działania w związku intymnym, czyli konstruujemy reprezentacje związków intymnych. I z całą pewnością różnią się one znacznie w zależności od habitusu rodzajowego.

Według słów Bourdieu „habitus to nieskończona, przy pełnej (kontrolowanej) swobodzie, zdolność wyłaniania wytworów - myśli, postrzeżeń, ekspresji, działań - które zawsze są ograniczone przez historycznie i społecznie zdefiniowane warunki produkcji, zapewniana przezeń warunkowa i uwarunkowana wolność jest 
odległa zarówno od tworzenia nieprzewidywalnej nowości, jak i od prostej mechanicznej reprodukcji pierwotnych uwarunkowań" (Bourdieu 2008, s. 75). Zatem wszystkie nowo tworzone związki są wypadkową: poprzednich doświadczeń indywidualnych i zbiorowych, zinternalizowanej wiedzy - indywidualnej i zbiorowej - na temat związków oraz praktyk, które są jednocześnie wytworem tych doświadczeń i próbą dostosowania do nowych obiektywnych warunków.

Korzystając z dorobku teorii praktyk Bourdieu, można stwierdzić, że praktyki związane z funkcjonowaniem w związku są wytwarzane przez habitus. Habitus jest ustrukturyzowaną strukturą strukturującą. To oznacza, że cały proces socjalizacji i przyswojone normy i wartości charakterystyczne dla klasy społecznej, z której się wywodzimy, sprawiają, że mamy odrębne wyobrażenia i oczekiwania na temat związków. Dlatego podejmujemy różne zachowania w związkach i oczekujemy różnych konsekwencji tych zachowań. Różny może być też stan dopasowania praktyk do warunków obiektywnych. Relacje w związku są zatem nieustannie (re)negocjowane i kształtowane przez dyskurs i w dyskursie.

W oparciu o koncepcję przemocy symbolicznej można stwierdzić, że w dyskursie widoczna jest jedna perspektywa - heteronormatywna. Dominuje ona w każdym z wymienionych dyskursów miłości. W tradycyjne pojmowanie gospodarstwa domowego i rodziny wpisana jest asymetria relacji władzy. Tradycyjnie pojmowana rodzina jest odbiciem stosunków władzy panujących w społeczeństwie, gdzie kobiety są grupą zdominowaną, co znajduje wyraz w systemie symbolicznych praktyk naturalizujących porządek społeczny z dominującą pozycją mężczyzn. Najpełniej owe praktyki uwidaczniają się w procesie rodzajowej socjalizacji, nakierowanej na utrzymanie tradycyjnego porządku i męskiego status quo.

Przemoc symboliczna sprawia, że w dominujące dyskursy miłości wpisane są wartości, normy i perspektywa oglądu grupy dominującej - heteroseksualnych mężczyzn. $\mathrm{Z}$ tej perspektywy $\mathrm{w}$ każdym $\mathrm{z}$ dyskursów dobrze funkcjonujący związek opiera się na poświęceniu kobiety. Jest to jedna z niewidocznych determinant funkcjonowania w związku, warunkowana przez kobiecy habitus.

Heteronormatywnej matrycy $w$ świecie związków intymnych można jeszcze dokładniej przyjrzeć się, stosując ramy interpretacyjne zaczerpnięte z prac Foucaulta (2000a; 2000b). W krytycznej analizie szczególnie istotne wydają się dwa elementy:

1) rozumienie płci i seksualności jako kategorii normatywnych, porządkujących,

2) traktowanie płci jako konstruktu służącego kontroli seksualności.

Kategorie płci i seksualności są narzędziami utrzymywania heteronormatywnego porządku. Wpisany jest $\mathrm{w}$ nie dyskurs władzy. Pole rodzinne, a w nim obszar relacji między partnerami, jest raczej areną nieustannych walk o władzę niż ostoją spokoju i bezpieczeństwa. Nie dostrzega się tego w żadnym z dominujących dyskursów.

W przeważającej liczbie opracowań i rozważań społeczno-pedagogicznych nieczęsto pojawia się fenomen władzy ${ }^{1}$. Relacje w związkach są raczej interpretowane

1 Wyjątkiem jest publikacja: Eugenii Mandal (2011). 
jako poszukiwanie konsensusu. Jak zauważyła Eugenia Mandal, badacze zdają się zakładać, że rodzina to najbardziej sielankowe miejsce $w$ świecie, $w$ którym władza czy walka o władzę nie istnieje. Tymczasem obecna jest ona w wielu zjawiskach zachodzących w małżeństwie i rodzinie, która dla większości ludzi stanowi fundamentalną wartość i źródło szczęścia. Jednocześnie to właśnie rodzina przez kryminologów nazywana bywa "najbardziej niebezpiecznym miejscem na Ziemi po zmierzchu" (Mandal 2011, s. 161). Wydaje się też, że rozpowszechnione rozumienie intymności nie uwzględnia pierwiastka wzajemnego ścierania się partnerów, ani też przeplatania się elementów zrozumienia, bliskości i wsparcia z elementami poświęcenia, poczucia krzywdy i zadośćuczynienia, czy wręcz zemsty.

Dyskursywnie kształtowany binaryzm płci pozostaje w służbie heteronormatywności - nie dopuszcza się wszelkiej „inności” w relacjach. Binaryzm płci i dyspozycji postrzeganych jako "naturalne” dla każdej nich sprawia, że wszelkie nienormatywne zachowania $\mathrm{w}$ obrębie związku są odrzucane, ukrywane przez partnerów, a w momencie ich odkrycia przez otoczenie - piętnowane społecznie. Dotyczy to zwłaszcza związków homoseksualnych, które są najczęściej ukrywane przed otoczeniem (taki jest społeczny wymóg), a odkryte, ujawnione, są stale "przykrawane" do norm charakterystycznych dla związków heteroseksualnych i według takich norm oceniane. Perspektywa krytyczna, dzięki demaskacji ukrytych aspektów relacji, pozwala eksplorować przestrzeń doświadczeń partnerów w związkach homoseksualnych bez tej heteronormatywnej kliszy. Reprezentacje społeczne jawią się w tym kontekście jako neutralna kategoria analityczna, gdyż nie kładą nacisku na kwestie pełnienia ról społecznych związanych z płcią. Zauważyć należy jednak, że sam proces konstruowania reprezentacji społecznych na temat związków u osób homoseksualnych jest także zdominowany przez heteronormatywne schematy socjalizacyjne. Jednak już w procesie ich modyfikacji większą rolę zdają się pełnić przeszłe doświadczenia, a mniejszą czynniki socjalizacyjne (głównie z uwagi na znikome występowanie takich wzorców w przestrzeni publicznej).

Dialektyka upodmiotawiania i podporządkowania nazywana przez Foucaulta uJArzmianiem zachodzi $\mathrm{w}$ procesie socjalizacji, przez zachowania noszące znamiona przemocy symbolicznej. Medykalizacja, widoczna zwłaszcza w tradycyjnym dyskursie miłości, jest narzędziem kontroli podporządkowanym imperatywom moralności. Wyrazem tego typu tendencji są np. spory $\mathrm{w}$ dyskursie politycznym skoncentrowane wokół antykoncepcji czy też zauważanie i poddawanie wartościowaniu zachowań niezgodnych z normami grup dominujących, nazywanych $\mathrm{w}$ dyskursie dewiacjami i wypaczeniami itp. To, co intymne zostaje wtłoczone w mechanizm wykluczeń, pustych miejsc w systemie wiedzy i władzy społeczeństwa.

I tak jak według Foucaulta dyskurs na temat seksu zdaje się skrywać swą problematykę (im więcej się o seksie mówi, tym większy staje się skrywający go „parawan" dyskursu), tak i w przypadku miłości dominujące jej dyskursy sprawiają, że prawdziwa natura jednego z jej składników - intymności - staje się coraz bardziej zakryta (Foucault 2000a, s. 52-53). Neutralizowaniu dyskursów służy wspólnota 
i oczywistość doświadczeń intymnych. Dyskursy miłości mają za zadanie utrzymać kobiety w stanie podporządkowania - zwłaszcza rygorom atrakcyjności, co wymaga stosowania szeregu praktyk modyfikujących wygląd zewnętrzny i mających za zadanie wywoływanie uczucia przyjemności u partnera na wiele różnych sposobów. Wyznacznikiem tych praktyk jest dyskurs, a jego nośnikami są zarówno nauka, jak i masowe media, popularne poradniki, praktyka psychologiczna czy proces socjalizacji.

Podsumowując, teoria krytyczna może pozwolić w badaniach dotknąć tego, co dominujące dyskursy, mówiąc o miłości, stale i niezmiennie skrywają, m.in. "mrocznych", strukturalnych uwarunkowań miłości i intymności. Stwarza także możliwość wyodrębnienia jednolitych kryteriów interpretacji danych na temat doświadczania intymności w związkach zarówno przez osoby o orientacji hetero-, jak i homoseksualnej. Ponadto pozwala dotknąć aspektów konstruowania społecznych reprezentacji związków i roli dyskursu publicznego $w$ tym procesie, przez co staje się jedną z najbardziej obiecujących perspektyw oglądu współczesnych - dynamicznych i negocjowalnych - relacji intymnych.

\section{Literatura:}

Bourdieu P., 2005, Dystynkcja. Społeczna krytyka władzy sadzenia, tłum. P. Biłos, Wyd. Naukowe Scholar, Warszawa.

Bourdieu P., 2008, Zmyst praktyczny, tłum. M. Falski, Wyd. UJ, Kraków.

Foucault M., 2000, Historia seksualności, tłum. B. Banasiak, T. Komendant, K. Matuszewski, t. I, II, III, Wyd. Czytelnik, Warszawa.

Foucault M., 2000, Seksualność $i$ władza [w:] M. Foucault, Filozofia, historia, polityka. Wybór pism, tłum. D. Leszczyński, L. Rasiński, Wydawnictwo Naukowe PWN, WarszawaWrocław.

Gdula M., 2009, Trzy dyskursy miłosne, Oficyna Naukowa, Warszawa.

Kocik L., 2006, Rodzina w obliczu wartości i wzorów życia ponowoczesnego świata, Oficyna Wydawnicza AFM, Kraków.

Ostrouch-Kamińska J., 2011, Rodzina partnerska jako relacja wspótzależnych podmiotów, Oficyna Wydawnicza „Impuls”, Kraków.

Mandal E., 2011, Mitość, władza i manipulacja w bliskich związkach, Wyd. Naukowe PWN, Warszawa.

Sternberg R.J., 2007, Dwuskładnikowa teoria miłości [w:] Nowa psychologia miłości, R.J. Sternberg, K. Weis (red.), tłum. A. Sosenko, Wyd. Moderator, Taszów.

Wojciszke B., 2010, Psychologia mitości, Gdańskie Wydawnictwo Psychologiczne, Gdańsk.

Wojciszke B., 2011, Psychologia społeczna, Wyd. Naukowe Scholar, Warszawa. 


\section{Summary}

Critical perspective in the exploration of meanings of intimacy

This paper is designed to provide the most relevant scientific definitions of what we used to call "intimacy", but also to "demystify" a bit this sphere of human experience. At the same time the author tries to show the usefulness of a critical perspective in the exploration of multiple meanings of intimacy. They are inextricably linked with the discourses of lovevariable over time and continuously prone to numerous modifications. They are constantly present in the public sphere and they penetrate the world of science, contributing to the dominance of a single, relatively rigid schema of interpretation of existing research on the most intimate areas of everyday life.

Keywords

intimacy, love, everyday life, privacy, change

\section{Słowa kluczowe}

intymność, miłość, codzienność, prywatność, zmiana 